\title{
Pola makan dan konsumsi alkohol sebagai faktor risiko hipertensi pada lansia
}

\author{
Eating pattern and alcohol consumption as risk factors of hypertension in the elderly
}

Nancy Swanida Henriette Malonda ${ }^{1}$, Lucia Kris Dinarti ${ }^{2}$, Retno Pangastuti ${ }^{3}$

\begin{abstract}
Background: Hypertension is one of the major chronic diseases in the elderly and the prevalence is constantly increasing. The results of Health Research Survey (Riskesdas) in 2007 showed that the prevalence of hypertension in the city of Tomohon was $41.6 \%$. The prevalence of fatty foods consumption in Tomohon was relatively high, amounted to $17.2 \%$. The proportion of alcohol consumer in North Sulawesi province was higher (17.4\%) than the National proportion (4.6\%), and Tomohon has significantly higher alcohol consumers (36\%). The consumption pattern of fatty foods and alcoholic beverages were factors that might increase the risk of hypertension.

Objective: To identify the influence of eating pattern and alcohol consumption as risk factors of hypertension in the elderly at Tomohon Municipality.

Method: This is an analytic observational study with case control design. Subjects were elderly people aged $60-65$ years at Tomohon Municipality consisted of 76 cases (hypertensive) and 76 control (non-hypertensive). Data was collected through structured interviews, food frequency questionaire (FFQ) was used to assess dietary pattern, mental health questionnaire (Self Reporting Questionnaire) was used to determine the condition of stress, waist-hip ratio measurement for obesity status, and blood pressure measurements. Data were analysed by bivariate and multiple logistic regression analysis.

Result: The result of bivariate analysis showed that fat intake (OR=3.046; 95\% Cl:1.338 - 6.933; $p=0.008)$, alcohol consumption (OR=2.8; 95\% Cl:1.418 - 5.299; $p=0.003)$, and obesity (OR=2.4; 95\% Cl:1.072 - 5.404; $p=0.033$ ) significant increase the risk of hypertension. The intake of natrium, potassium and calcium, family history, smoking and stress showed no significant association with hypertension. Statistical analysis revealed that the variables that become dominant risk factors for hypertension and affected the incidence of hypertension were fat (OR=3.303; 95\% Cl:1.346 8.10; $p=0.009$ ) and alcohol consumption (OR=2.792; 95\% Cl:1.347-5.789; $p=0.006)$.

Conclusion: High fat and alcohol consumption were risk factors that affect the incidence of hypertension amongst the elderly at Tomohon Municipality.
\end{abstract}

KEYWORDS hypertension, eating pattern, fat, alcohol consumption, elderly

\begin{abstract}
ABSTRAK
Latar belakang: Hipertensi adalah salah satu penyakit kronis utama pada lanjut usia dan terus mengalami peningkatan. Hasil Riset Kesehatan Dasar (Riskesdas) tahun 2007 menunjukkan bahwa prevalensi hipertensi di Kota Tomohon sebesar 41,6\%. Prevalensi penduduk Kota Tomohon yang mengonsumsi makanan berlemak tergolong tinggi yaitu 17,2\%. Konsumsi alkohol di Provinsi Sulawesi Utara adalah yang tertinggi $(17,4 \%)$ dari data Nasional $(4,6 \%)$ dan di Kota Tomohon juga didapatkan 36\% yang mengonsumsi alkohol. Pola konsumsi makanan berlemak dan minuman beralkohol adalah faktor yang dapat memicu terjadinya hipertensi.

Tujuan: Penelitian ini bertujuan untuk mengetahui pengaruh pola makan dan konsumsi alkohol sebagai faktor risiko hipertensi pada lansia di kota Tomohon.

Metode: Jenis penelitian ini adalah analitik observasional dengan rancangan penelitian case control study. Sampel dalam penelitian ini yaitu lansia di Kota Tomohon yang berumur 60-65 tahun, sebanyak 76 sampel untuk kasus hipertensi dan 76 sampel untuk kontrol (tidak hipertensi). Pengumpulan data dilakukan dengan wawancara terstruktur, food frequency questionaire (FFQ) untuk mengetahui pola makan, kuesioner kesehatan mental (Self Reporting Questionnaire) untuk mengetahui kondisi stres, pengukuran rasio lingkar pinggang panggul untuk status obesitas, serta pengukuran tekanan darah. Analisis dilakukan secara bivariat dan multiple logistic regression.

Hasil: Hasil uji bivariat didapatkan asupan lemak (OR=3,046; 95\% Cl:1,338 - 6,933; $p=0,008$ ), konsumsi alkohol (OR=2,8; 95\% Cl:1,418 - 5,299; $p=0,003$ ), dan obesitas (OR=2,4; 95\% Cl:1,072 - 5,404; $p=0,033$ ) memiliki pengaruh yang bermakna terhadap kejadian hipertensi. Hasil analisis pada asupan natrium, asupan kalium, asupan kalsium, riwayat keluarga, merokok, dan stres diperoleh hasil yang tidak bermakna $(p>0,05)$. Hasil uji multivariat menunjukkan
\end{abstract}

${ }^{1}$ Fakultas Kesehatan Masyarakat Universitas Sam Ratulangi, Jl. Kampus Unsrat Kleak Manado 95115, e-mail: nancymalonda@yahoo.com ${ }^{2}$ Bagian Kardiologi dan Kedokteran Vaskuler, Fakultas Kedokteran Universitas Gadjah Mada, JI. Farmako, Sekip Utara, Yogyakarta 55281

${ }^{3}$ Instalasi Gizi Rumah Sakit Umum Pusat Dr. Sardjito, Jl. Kesehatan No 1, Yogyakarta 55281, e-mail: retnopangastuti@gmail.com 
variabel yang paling berisiko dan mempengaruhi terjadinya hipertensi yaitu asupan lemak (OR=3,303; 95\% Cl:1,346 8,10; $p=0,009)$ dan konsumsi alkohol (OR=2,792; 95\% Cl:1,347 - 5,789; $p=0,006)$.

Kesimpulan: Pola makan tinggi lemak dan konsumsi alkohol merupakan faktor risiko yang mempengaruhi terjadinya hipertensi pada lansia di Kota Tomohon.

KATA KUNCI: hipertensi, pola makan, konsumsi alkohol, lansia

\section{PENDAHULUAN}

Di Indonesia, saat ini hipertensi adalah faktor risiko ketiga terbesar yang menyebabkan kematian dini terkait penyakit jantung dan pembuluh darah (1). Bahkan hipertensi berdampak pula pada penurunan kualitas hidup (2). Hipertensi adalah salah satu penyakit kronis utama yang diderita lanjut usia (3). Angka harapan hidup penduduk Indonesia semakin meningkat dari 70,7 tahun pada tahun 2009 menjadi 70,9 tahun pada tahun 2010. Termasuk angka harapan hidup penduduk Sulawesi Utara, didapatkan lebih tinggi dari data nasional yaitu 74,9 tahun (4).

Pada tahun 2008 angka kesakitan masyarakat menunjukkan bahwa hipertensi merupakan penyakit terbanyak di Puskesmas yaitu 13.246 kasus (33,83\%) (5). Data riset kesehatan dasar (Riskesdas) 2007 menunjukkan prevalensi hipertensi berdasarkan hasil pengukuran tekanan darah untuk kota Tomohon sebesar $41,6 \%$. Hipertensi merupakan masalah yang sering ditemukan pada lansia, termasuk lansia di Kota Tomohon. Data yang ada menunjukkan penduduk lansia seluruhnya berjumlah 15.904 jiwa, dikelompokkan menjadi pra lansia (45-59 tahun) berjumlah 8.842 jiwa dan lansia ( $\geq 60$ tahun) berjumlah 7.062 jiwa (6).

Faktor pemicu hipertensi dapat dibedakan menjadi faktor yang tidak dapat dikontrol dan faktor yang dapat dikontrol. Umur, jenis kelamin, dan keturunan termasuk faktor yang tidak dapat dikontrol, sedangkan faktor yang dapat dikontrol antara lain obesitas, stres, kurang olahraga, merokok, serta konsumsi alkohol dan garam (7). Telah dibuktikan juga dalam penelitian bahwa konsumsi alkohol setiap hari dapat meningkatkan tekanan darah sistolik sebesar 1,21 $\mathrm{mmHg}$ dan tekanan darah diastolik sebesar $0,55 \mathrm{mmHg}$ untuk rata-rata satu kali minum per hari (8). Pada perjalanannya hipertensi juga dipengaruhi oleh pola makan (7).

Gaya hidup yang tidak sehat pada masyarakat kota Tomohon saat ini terlihat pada prevalensi penduduk yang mengonsumsi makanan berisiko atau berlemak sebesar $17,2 \%$. Jika dibandingkan dengan angka rata-rata di Sulawesi Utara $(7,3 \%)$ dan angka rata-rata nasional $(12,8 \%)$ maka masyarakat Kota Tomohon tergolong tinggi konsumsi makanan berlemaknya (6). Kebiasaan minum alkohol juga menjadi bagian dari masyarakat yang berdomisili di wilayah Kota Tomohon. Data Riskesdas tahun 2007 menggambarkan prevalensi penduduk di Kota
Tomohon yang mengonsumsi alkohol dalam 12 bulan terakhir sebesar $36 \%$. Masyarakat Provinsi Sulawesi Utara juga tergolong tinggi pola konsumsi alkoholnya $(17,4 \%)$ dibanding rata-rata Nasional yaitu 4,6\%. Demikian juga prevalensi konsumsi minuman beralkohol dalam satu bulan terakhir, ditemukan prevalensi tertinggi di Kota Tomohon (31\%) (6). Setiap masyarakat memiliki persepsi yang berbeda mengenai benda yang dikonsumsi. Perbedaan persepsi ini, sangat dipengaruhi oleh nilai dan norma budaya yang berlaku di masyarakatnya (9). Oleh karena itu, penelitian ini bertujuan untuk mengetahui pengaruh pola makan (konsumsi lemak, natrium, kalium, kalsium) dan konsumsi alkohol terhadap terjadinya hipertensi pada lansia di Kota Tomohon.

\section{BAHAN DAN METODE}

Penelitian ini adalah penelitian analitik dengan rancangan case control (kasus - kontrol) dengan matching variabel umur dan jenis kelamin. Penelitian dilaksanakan di wilayah kerja Puskesmas Tomohon Utara, Tomohon Tengah, dan Tomohon Selatan di Kota Tomohon. Populasi penelitian adalah seluruh lansia berusia 60-65 tahun yang tinggal di Kota Tomohon. Sampel yaitu lansia yang ada di Kota Tomohon yang memenuhi kriteria inklusi yaitu berusia 60-65 tahun, berdomisili di Kota Tomohon, dan tinggal bersama keluarga. Sedangkan lansia yang mengalami gangguan berkomunikasi dan daya ingat dieksklusi dalam penelitian ini. Kelompok kasus adalah lansia yang memeriksakan diri ke puskesmas pada periode Oktober 2008 sampai dengan September 2009, dilakukan pemeriksaan klinis, pengukuran tekanan darah oleh dokter, dan didiagnosis hipertensi. Kemudian secara random ditentukan responden yang akan menjadi subjek penelitian dengan menggunakan tabel random dan dilakukan penjaringan dengan tes penentuan fungsi kognitif untuk mendapatkan subjek penelitian yang kemampuan mengingatnya baik atau tidak ada gangguan daya ingat. Tes penentuan fungsi kognitif ini menggunakan kuesioner Mini Mental State Examination (MMSE).

Subjek dinyatakan hipertensi jika hasil pengukuran tekanan darah lebih dari atau sama dengan $140 / 90 \mathrm{mmHg}$ (10). Kelompok kontrol adalah lansia yang tidak menderita hipertensi atau tidak memiliki riwayat hipertensi serta bersedia menjadi subjek penelitian. Besar sampel dihitung dengan menggunakan rumus untuk studi kasus kontrol berpasangan dengan tingkat kepercayaan $\left(Z_{\alpha}\right) 95 \%(1,96)$, power $\left(Z_{\beta}\right) 20 \%$ 
$(0,842), \mathrm{OR}=2$ (yang dianggap bermakna) sehingga besar sampel minimal yang dibutuhkan adalah 74 sampel (11). Jumlah sampel yang digunakan yaitu 76 sampel sebagai kelompok kasus dan 76 sampel sebagai kelompok kontrol.

Pola makan adalah asupan dan frekuensi jenis makanan sumber lemak, natrium, kalsium, dan kalium yang dikonsumsi sehari-hari. Kriteria asupan lemak dibagi menjadi lebih (> 25\%) dan cukup ( $\leq 25 \%)(12)$; asupan natrium dikategorikan menjadi lebih ( $\geq 2300 \mathrm{mg}$ ) dan kurang ( $<2300 \mathrm{mg}$ ); asupan kalsium dikategorikan menjadi lebih ( $\geq 800 \mathrm{mg}$ ) dan kurang (<800 mg); asupan kalium dikategorikan menjadi lebih ( $\geq 2000 \mathrm{mg}$ ) dan kurang $(<2000$ $\mathrm{mg}$ ). Frekuensi konsumsi lemak jenuh dan tidak jenuh dibagi dalam kategori sering (frekuensi $\geq 1$ kali per minggu) dan jarang (frekuensi konsumsi < 1 kali per minggu), demikian pula dengan frekuensi konsumsi natrium yang dikategorikan menjadi sering ( $\geq 3$ kali per hari) dan jarang ( $<3$ kali per hari). Konsumsi alkohol adalah kebiasaan mengonsumsi minuman yang mengandung alkohol dari subjek penelitian dalam waktu minimal 12 bulan terakhir (6) yang diperinci berdasarkan jenis, jumlah, frekuensi, dan lama konsumsi.

Pengumpulan data dilakukan dengan wawancara terstruktur, formulir food frequency questionaire (FFQ) untuk mengetahui pola makan dalam 3 bulan terakhir, kuesioner kesehatan mental yaitu Self Reporting Questionnaire (SRQ) sebagai panduan untuk mendapatkan data kondisi stres pada lansia, serta pengukuran tekanan darah menggunakan sphygmomanometer air raksa dan stetoskop. Status obesitas diketahui dengan pengukuran lingkar pinggang dan panggul menggunakan pita meteran non elastic / meterline merek Seca dengan tingkat ketelitian $0,1 \mathrm{~cm}$ dengan batas normal atau tidak obesitas jika rasio lingkar pinggang panggul (RLPP) kurang dari 0,9 pada pria dan kurang dari 0,8 pada wanita (1). Analisis data dengan uji statistik Chi Square dilakukan untuk mengetahui pengaruh antara pola makan, konsumsi alkohol, obesitas, riwayat keluarga, merokok, dan stres dengan hipertensi, kemudian untuk mengetahui faktor risiko yang paling berpengaruh dilakukan analisis multivariat menggunakan uji regresi logistik ganda.

\section{HASIL}

\section{Karakteristik subjek penelitian}

Berdasarkan umur, paling banyak subjek berumur 63 - 65 tahun dan lebih banyak lansia perempuan $(65,8 \%)$. Jika dilihat berdasarkan umur dan jenis kelamin tidak ada perbedaan antara kelompok kasus dan kontrol karena telah dilakukan matching (Tabel 1).

\section{Pengaruh pola makan terhadap hipertensi}

Pengaruh asupan lemak terhadap hipertensi. Hasil penelitian ini menunjukkan bahwa lansia yang
Tabel 1. Karakteristik responden

\begin{tabular}{|c|c|c|c|c|c|c|}
\hline \multirow{2}{*}{ Karakteristik } & \multicolumn{2}{|c|}{ Hipertensi } & \multicolumn{2}{|c|}{$\begin{array}{c}\text { Tidak } \\
\text { hipertensi }\end{array}$} & \multicolumn{2}{|c|}{ Jumlah } \\
\hline & $\mathbf{n}$ & $\%$ & $\mathbf{n}$ & $\%$ & $\mathbf{n}$ & $\%$ \\
\hline \multicolumn{7}{|l|}{ Umur (tahun) } \\
\hline $60-62$ & 32 & 50 & 32 & 50 & 64 & 50 \\
\hline $63-65$ & 44 & 50 & 44 & 50 & 88 & 50 \\
\hline \multicolumn{7}{|l|}{ Jenis kelamin } \\
\hline Laki-laki & 26 & 34,2 & 26 & 34,2 & 52 & 34,2 \\
\hline Perempuan & 50 & 65,8 & 50 & 65,8 & 100 & 65,8 \\
\hline \multicolumn{7}{|l|}{ Pekerjaan } \\
\hline Tidak bekerja & 28 & 36,8 & 29 & 38,2 & 57 & 37,5 \\
\hline Tani & 23 & 30,3 & 19 & 25,0 & 42 & 27,6 \\
\hline Swasta & 3 & 3,9 & 4 & 5,2 & 7 & 4,6 \\
\hline Pensiunan & 22 & 28,9 & 24 & 31,6 & 46 & 30,3 \\
\hline $\begin{array}{l}\text { Tekanan darah } \\
(\mathrm{mmHg})\end{array}$ & \multicolumn{3}{|c|}{ Kasus } & \multicolumn{3}{|c|}{ Kontrol } \\
\hline Sistolik & \multicolumn{3}{|c|}{$143,36 \pm 18,35$} & \multicolumn{3}{|c|}{$121,49 \pm 8,94$} \\
\hline Diastolik & \multicolumn{3}{|c|}{$90,26 \pm 8,74$} & \multicolumn{3}{|c|}{$78,50 \pm 6,31$} \\
\hline
\end{tabular}

asupan lemaknya lebih dari $25 \%$ total kalori sehari lebih banyak ditemukan pada kelompok hipertensi $(31,6 \%)$ dibanding pada kelompok tidak hipertensi $(13,2 \%)$. Berdasarkan hasil analisis didapatkan bahwa lansia dengan rata-rata asupan lemak lebih dari $25 \%$ total kalori per hari mempunyai risiko 3,046 lebih besar untuk mengalami hipertensi dibandingkan dengan lansia yang rata-rata asupan lemaknya kurang dari atau sama dengan $25 \%$ total kalori per hari (Tabel 2).

Pada kelompok yang menderita hipertensi, 52,6\% lansia sering mengonsumsi lemak jenuh sedangkan lansia yang tidak hipertensi hanya $25 \%$ yang sering mengonsumsi. Hasil penelitian diperoleh bahwa lansia yang sering mengonsumsi lemak jenuh mempunyai risiko 3,333 kali lebih tinggi untuk mengalami hipertensi dibandingkan dengan lansia yang jarang mengonsumsi lemak jenuh. Lansia yang sering mengonsumsi lemak tidak jenuh, didapatkan 3,9\% yang mengalami hipertensi dan $15,8 \%$ yang tidak hipertensi, tetapi secara keseluruhan lansia dalam subjek penelitian ini jarang mengonsumsi lemak tidak jenuh. Hasil analisis menunjukkan lansia yang sering mengonsumsi lemak tidak jenuh mempunyai risiko 0,219 kali lebih rendah untuk mengalami hipertensi. Penelitian ini membuktikan adanya pengaruh antara asupan lemak serta frekuensi konsumsi lemak jenuh dan lemak tidak jenuh dengan terjadinya hipertensi $(p<0,05)$ dan asam lemak tidak jenuh merupakan faktor protektif terhadap hipertensi.

Pengaruh asupan natrium terhadap hipertensi. Hasil penelitian menunjukkan bahwa lansia yang asupan natriumnya lebih dari atau sama dengan $2300 \mathrm{mg}$ lebih banyak ditemukan pada kelompok hipertensi $(5,3 \%)$ sedangkan pada kelompok yang tidak hipertensi sebesar $2,6 \%$. Penelitian ini menunjukkan tidak ada pengaruh yang bermakna antara asupan natrium $(\mathrm{OR}=2,055 ; \mathrm{Cl}$ 95\%:0,365-11,573; $p>0,05)$ dan frekuensi konsumsi 
Tabel 2. Pengaruh pola makan terhadap hipertensi

\begin{tabular}{|c|c|c|c|c|c|c|}
\hline \multirow[t]{2}{*}{ Variabel } & \multicolumn{2}{|c|}{ Hipertensi } & \multicolumn{2}{|c|}{$\begin{array}{c}\text { Tidak } \\
\text { hipertensi }\end{array}$} & \multirow{2}{*}{$\begin{array}{c}\text { OR } \\
\text { (Cl 95\%) }\end{array}$} & \multirow{2}{*}{$\mathbf{p}$} \\
\hline & $\mathbf{n}$ & $\%$ & $n$ & $\%$ & & \\
\hline \multicolumn{7}{|l|}{ Asupan lemak } \\
\hline Lebih (> 25\%) & 24 & 31,6 & 10 & 13,2 & 3,046 & $0,008^{*}$ \\
\hline Cukup $(\leq 25 \%)$ & 52 & 44,1 & 66 & 55,9 & $(1,338-6,933)$ & \\
\hline Total & 76 & 100 & 76 & 100 & & \\
\hline \multicolumn{7}{|l|}{ Konsumsi lemak jenuh } \\
\hline Sering & 40 & 52,6 & 19 & 25,0 & 3,333 & $0,001^{*}$ \\
\hline Jarang & 36 & 47,4 & 57 & 75,0 & $(1,676-6,627)$ & \\
\hline Total & 76 & 100 & 76 & 100 & & \\
\hline \multicolumn{7}{|c|}{ Konsumsi lemak tidak jenuh } \\
\hline Sering & 3 & 3,9 & 12 & 15,8 & 0,219 & $0,023^{*}$ \\
\hline Jarang & 73 & 96,1 & 64 & 84,2 & $(0,059-0,811)$ & \\
\hline Total & 76 & 100 & 76 & 100 & & \\
\hline \multicolumn{7}{|l|}{ Asupan natrium } \\
\hline Lebih ( $\geq 2300$ mg) & 4 & 5,3 & 2 & 2,6 & 2,055 & 0,414 \\
\hline Kurang $(<2300 \mathrm{mg})$ & 72 & 94,7 & 74 & 97,4 & $(0,365-11,573)$ & \\
\hline Total & 76 & 100 & 76 & 100 & & \\
\hline \multicolumn{7}{|l|}{ Konsumsi natrium } \\
\hline Sering & 3 & 3,9 & 4 & 5,3 & 0,739 & 0,700 \\
\hline Jarang & 73 & 96,1 & 72 & 94,7 & $(0,159-3,423)$ & \\
\hline Total & 76 & 100 & 76 & 100 & & \\
\hline \multicolumn{7}{|l|}{ Asupan kalium } \\
\hline Lebih ( $\geq 2000$ mg) & 49 & 64,5 & 39 & 51,3 & 1,72 & 0,102 \\
\hline Kurang $(<2000 \mathrm{mg})$ & 27 & 35,5 & 37 & 48,7 & $(0,898-3,299)$ & \\
\hline Total & 76 & 100 & 76 & 100 & & \\
\hline \multicolumn{7}{|l|}{ Asupan kalsium } \\
\hline Lebih ( $\geq 800$ mg) & 9 & 11,8 & 8 & 10,5 & 1,141 & 0,797 \\
\hline Kurang (<800 mg) & 67 & 88,2 & 68 & 89,5 & $(0,416-3,136)$ & \\
\hline Total & 76 & 100 & 76 & 100 & & \\
\hline
\end{tabular}

Keterangan: *Bermakna $(p<0,05)$

natrium (OR=0,739; Cl 95\%:0,159-3,423; p>0,05) dengan kejadian hipertensi (Tabel 2).

Pengaruh asupan kalium terhadap hipertensi. Hasil penelitian menunjukkan tidak adanya pengaruh yang bermakna antara asupan kalium dengan kejadian hipertensi $(p=0,102)$. Lansia dengan asupan kalium lebih besar atau sama dengan 2000 mg, lebih banyak (64,5\%) pada kelompok hipertensi dibandingkan pada kelompok tidak hipertensi (51,3\%) (Tabel 2).

Pengaruh asupan kalsium terhadap hipertensi. Sebagian besar lansia asupan kalsiumnya kurang dari 800 mg. Subjek penelitian yang asupan kalsiumnya lebih besar atau sama dengan $800 \mathrm{mg}$, sebanyak $11,8 \%$ mengalami hipertensi dan 10,5\% tidak hipertensi. Tidak ada pengaruh yang bermakna antara asupan kalsium dengan kejadian hipertensi (OR=1,141; Cl 95\%:0,416-3,136; $p>0,05)$ (Tabel 2).

\section{Pengaruh konsumsi alkohol terhadap hipertensi}

Berdasarkan hasil penelitian didapatkan bahwa lansia yang mengonsumsi alkohol lebih banyak (50\%) pada kelompok hipertensi dibanding pada kelompok tidak hipertensi (26,3\%). Lansia yang mengonsumsi alkohol berisiko 2,8 kali lebih tinggi untuk menderita hipertensi dibandingkan dengan lansia yang tidak mengonsumsi alkohol $(p<0,05)$ (Tabel 3).

Hasil penelitian menunjukkan bahwa alkohol jenis Cap Tikus (minuman keras atau minuman berkadar alkohol tinggi yang diproduksi secara penyulingan tradisional di daerah Sulawesi Utara) lebih banyak (86,8\%) dikonsumsi lansia pada kelompok hipertensi dibanding kelompok tidak hipertensi (70\%). Lansia yang mengonsumsi alkohol setiap hari lebih banyak pada kelompok hipertensi dibandingkan pada kelompok tidak hipertensi. Lansia yang mengonsumsi alkohol setiap hari mempunyai risiko 8,84 kali lebih tinggi untuk menderita hipertensi dibanding lansia yang tidak mengonsumsi alkohol. Demikian juga untuk lansia yang mengonsumsi alkohol 1-4 kali per minggu, mempunyai risiko 2,54 kali lebih tinggi untuk mengalami hipertensi dibanding lansia yang tidak mengonsumsi alkohol. Lansia yang mengonsumsi 1-2 sloki minuman alkohol lebih banyak pada kelompok hipertensi $(60,5 \%)$ dibanding pada kelompok tidak 
Tabel 3. Pengaruh konsumsi alkohol terhadap hipertensi

\begin{tabular}{|c|c|c|c|c|c|c|}
\hline \multirow{2}{*}{ Variabel } & \multicolumn{2}{|c|}{ Hipertensi } & \multicolumn{2}{|c|}{ Tidak hipertensi } & \multirow{2}{*}{$\begin{array}{c}\text { OR } \\
\text { (Cl 95\%) }\end{array}$} & \multirow{2}{*}{$\mathbf{p}$} \\
\hline & $\mathbf{n}$ & $\%$ & $\mathbf{n}$ & $\%$ & & \\
\hline \multicolumn{7}{|l|}{ Konsumsi alkohol } \\
\hline $\mathrm{Ya}$ & 38 & 50 & 20 & 26,3 & 2,8 & $0,003^{*}$ \\
\hline Tidak & 38 & 50 & 56 & 73,7 & $(1,418-5,529)$ & \\
\hline Total & 76 & 100 & 76 & 100 & & \\
\hline \multicolumn{7}{|c|}{ Jenis minuman (kadar alkohol) } \\
\hline Cap Tikus (30-40\%) & 33 & 86,8 & 14 & 70 & $3,47(1,643-7,343)$ & $0,001^{*}$ \\
\hline Anggur (8-15\%) & 1 & 2,6 & 1 & 5 & $1,47(0,894-24,28)$ & 0,786 \\
\hline $\operatorname{Bir}(4-8 \%)$ & 2 & 5,3 & 3 & 15 & $0,98(0,156-6,161)$ & 0,985 \\
\hline Saguer $(<5 \%)$ & 2 & 5,3 & 2 & 10 & $1,47(0,198-10,91)$ & 0,704 \\
\hline Tidak konsumsi & 38 & 50 & 56 & 73,7 & Reference & \\
\hline Total & 76 & 100 & 76 & 100 & & \\
\hline \multicolumn{7}{|l|}{ Frekuensi konsumsi } \\
\hline Tiap hari & 12 & 31,6 & 2 & 35 & $8,84(1,871-41,76)$ & $0,006^{*}$ \\
\hline 1-4 kali per minggu & 19 & 50 & 11 & 55 & $2,54(1,088-5,950)$ & $0,031^{*}$ \\
\hline$<1$ kali per minggu & 7 & 18,4 & 7 & 10 & $1,47(0,478-4,542)$ & 0,500 \\
\hline Tidak konsumsi & 38 & 50 & 56 & 73,7 & Reference & \\
\hline Total & 76 & 100 & 76 & 100 & & \\
\hline \multicolumn{7}{|l|}{ Jumlah alkohol (sloki) } \\
\hline$>5$ & 4 & 10,5 & 5 & 25 & $1,17(0,297-4,675)$ & 0,815 \\
\hline $3-4$ & 1 & 2,6 & 0 & 0 & 0 & 0 \\
\hline $1-2$ & 23 & 60,5 & 8 & 40 & $4,23(1,716-10,46)$ & $0,002^{*}$ \\
\hline$<1$ & 10 & 26,3 & 7 & 35 & $2,10(0,736-6,016)$ & 0,165 \\
\hline Tidak konsumsi & 38 & 50 & 56 & 73,7 & Reference & \\
\hline Total & 76 & 100 & 76 & 100 & & \\
\hline \multicolumn{7}{|c|}{ Lamanya konsumsi (tahun) } \\
\hline $41-50$ & 18 & 23,7 & 7 & 9,2 & $3,78(0,513-16,90)$ & $0,007^{*}$ \\
\hline $31-40$ & 14 & 18,4 & 5 & 6,6 & $4,12(1,372-12,41)$ & $0,012^{*}$ \\
\hline $21-30$ & 1 & 1,3 & 3 & 3,9 & $0,49(0,492-4,901)$ & 0,545 \\
\hline $11-20$ & 2 & 2,6 & 4 & 5,3 & $0,73(0,128-4,226)$ & 0,732 \\
\hline $1-10$ & 3 & 3,9 & 1 & 1,3 & $4,42(0,443-44,11)$ & 0,205 \\
\hline Tidak konsumsi & 38 & 50 & 56 & 73,7 & Reference & \\
\hline Total & 76 & 100 & 76 & 100 & & \\
\hline
\end{tabular}

Ket: *Bermakna $(p<0,05)$

hipertensi (40\%). Lansia yang mengonsumsi alkohol 1-2 sloki setiap kali minum mempunyai risiko 4,23 kali terjadinya hipertensi dibanding yang tidak mengonsumsi alkohol.

Hasil penelitian menunjukkan bahwa pada lansia yang mengonsumsi alkohol selama 41-50 tahun dan 3140 tahun ditemukan adanya pengaruh yang bermakna terhadap terjadinya hipertensi. Masing-masing beresiko 3,78 kali dan 4,12 kali lebih tinggi untuk mengalami hipertensi dibanding yang tidak mengonsumsi alkohol. Sedangkan yang mengonsumsi alkohol selama 21-30 tahun dan 11-20 tahun, ditemukan sebagai faktor protektif tetapi tidak ada pengaruh yang bermakna. Demikian juga dengan subjek yang mengonsumsi alkohol selama 1-10 tahun, didapatkan tidak ada pengaruh bermakna walaupun dapat berisiko 4,4 kali lebih besar mengalami hipertensi dibanding yang tidak mengonsumsi alkohol.
Pengaruh obesitas, riwayat keluarga, merokok, dan stres terhadap hipertensi

Tabel 4 menunjukkan bahwa lansia yang obesitas, lebih banyak $(85,5 \%)$ mengalami hipertensi dibanding yang tidak hipertensi $(71,1 \%)$. Lansia yang obesitas mempunyai risiko 2,40 kali lebih tinggi untuk menderita hipertensi dibandingkan dengan lansia yang tidak obesitas $(p<0,05)$. Lansia yang memiliki riwayat keluarga hipertensi diketahui lebih banyak $(60,5 \%)$ pada kelompok hipertensi dibanding kelompok tidak hipertensi $(51,3 \%)$ namun hasil analisis menunjukkan tidak ada pengaruh bermakna antara riwayat keluarga hipertensi dengan kejadian hipertensi. Sebesar $14,5 \%$ lansia yang merokok mengalami hipertensi, hasil ini sama dengan lansia yang tidak hipertensi $(14,5 \%)$, sehingga hasil analisis menunjukkan tidak ada pengaruh bermakna antara merokok dengan terjadinya hipertensi. Pada lansia yang mengalami stres ditemukan 19,7\% lansia 
Tabel 4. Pengaruh obesitas, riwayat keluarga, merokok, dan stres terhadap hipertensi

\begin{tabular}{|c|c|c|c|c|c|c|}
\hline \multirow{2}{*}{ Variabel } & \multicolumn{2}{|c|}{ Hipertensi } & \multicolumn{2}{|c|}{ Tidak hipertensi } & \multirow{2}{*}{$\begin{array}{c}\text { OR } \\
\text { (Cl } 95 \%)\end{array}$} & \multirow{2}{*}{$\mathbf{p}$} \\
\hline & $n$ & $\%$ & $\mathbf{n}$ & $\%$ & & \\
\hline \multicolumn{7}{|l|}{ Obesitas } \\
\hline $\mathrm{Ya}$ & 65 & 85,5 & 54 & 71,1 & 2,40 & \multirow{3}{*}{$0,033^{*}$} \\
\hline Tidak & 11 & 14,5 & 22 & 28,9 & $(1,072-5,404)$ & \\
\hline Total & 76 & 100 & 76 & 100 & & \\
\hline \multicolumn{7}{|l|}{ Riwayat keluarga } \\
\hline $\mathrm{Ya}$ & 46 & 60,5 & 39 & 51,3 & 1,454 & \multirow{3}{*}{0,254} \\
\hline Tidak & 30 & 39,5 & 37 & 48,7 & $(0,764-2,768)$ & \\
\hline Total & 76 & 100 & 76 & 100 & & \\
\hline \multicolumn{7}{|l|}{ Merokok } \\
\hline $\mathrm{Ya}$ & 11 & 14,5 & 11 & 14,5 & 1 & \multirow{3}{*}{1,000} \\
\hline Tidak & 65 & 85,5 & 65 & 85,5 & $(0,405-2,468)$ & \\
\hline Total & 76 & 100 & 76 & 100 & & \\
\hline \multicolumn{7}{|l|}{ Stres } \\
\hline Ya & 15 & 19,7 & 9 & 11,8 & 1,830 & \multirow{3}{*}{0,186} \\
\hline Tidak & 61 & 80,3 & 67 & 88,2 & $(0,747-4,486)$ & \\
\hline Total & 76 & 100 & 76 & 100 & & \\
\hline
\end{tabular}

Ket: *Bermakna $(p<0,05)$

menderita hipertensi dan $11,8 \%$ lansia tidak menderita hipertensi. Hasil analisis membuktikan bahwa tidak ada pengaruh antara stres dengan terjadinya hipertensi.

\section{Faktor yang paling berpengaruh terhadap hipertensi}

Pada penelitian ini, variabel asupan lemak yang paling besar pengaruhnya terhadap terjadinya hipertensi. Hasil analisis multivariat (Tabel 5) menunjukkan nilai OR yang paling besar dari variabel asupan lemak yaitu 3,303 (95\% $\mathrm{Cl}: 1,346-8,109)$. Hasil ini menunjukkan bahwa lansia dengan rata-rata asupan lemak lebih dari $25 \%$ total kalori per hari mempunyai risiko 3,303 kali lebih besar untuk menderita hipertensi dibandingkan dengan lansia yang rata-rata asupan lemaknya kurang, setelah dikontrol variabel stres, asupan kalium, obesitas, dan konsumsi alkohol.

Tabel 5. Analisis multivariat faktor yang paling berpengaruh terhadap hipertensi

\begin{tabular}{lccc}
\hline \multicolumn{1}{c}{ Variabel } & OR & $\mathbf{p}$ & $\mathbf{9 5 \%} \mathbf{C l}$ \\
\hline Stres & 2,410 & 0,086 & $0,883-6,574$ \\
Asupan kalium & 1,948 & 0,068 & $0,951-3,990$ \\
Obesitas & 2,318 & 0,057 & $0,976-5,504$ \\
Asupan lemak & 3,303 & $0,009^{*}$ & $1,346-8,109$ \\
Konsumsi alkohol & 2,792 & $0,006^{*}$ & $1,347-5,789$ \\
\hline
\end{tabular}

Ket: *Bermakna $(p<0,05)$

\section{BAHASAN}

\section{Pola makan terhadap hipertensi}

Hasil penelitian ini menunjukkan adanya hubungan antara asupan lemak dengan terjadinya hipertensi. Konsumsi makanan yang tinggi lemak dapat menyebabkan aterosklerosis atau penyempitan pembuluh darah, akibatnya pembuluh darah menjadi kaku dan elastisitasnya berkurang. Kondisi ini akan mengakibatkan tahanan aliran darah dalam pembuluh darah menjadi naik. Naiknya tekanan sistolik yang diakibatkan oleh pembuluh darah yang tidak elastis dan naiknya tekanan diastolik yang diakibatkan oleh penyempitan pembuluh darah, disebut dengan tekanan darah tinggi (7). Peningkatan jumlah asam lemak bebas juga akan mempersempit pembuluh darah sehingga tekanan darah meningkat (13). Berbeda dengan penelitian yang dilakukan di Puskesmas Curup dan Perumnas Kabupaten Rejang Lebong Provinsi Bengkulu, hasilnya menunjukkan bahwa tidak terdapat pengaruh yang bermakna asupan lemak terhadap kejadian hipertensi esensial setelah dikontrol faktor lain (14).

Pada penelitian ini diketahui bahwa hampir semua lansia mempunyai kebiasaan mengonsumsi makanan khas Minahasa yang sebagian besar mengandung asam lemak jenuh tinggi yang merupakan salah satu faktor risiko terjadinya hipertensi. Sehingga dapat dibuktikan bahwa lansia yang sering mengonsumsi lemak jenuh mempunyai risiko 3,333 kali lebih tinggi untuk menderita hipertensi dibandingkan dengan lansia yang jarang mengonsumsi lemak jenuh.

Etnis Minahasa termasuk sebagian besar lansia di kota Tomohon, mempunyai kebiasaan budaya 'pesta' dalam pengertian kebiasaan mengonsumsi makanan sumber asam lemak jenuh tinggi yaitu lemak hewani, seperti ayam rica, RW (daging anjing), tikus rica, dan berbagai makanan yang terbuat dari daging babi. Jenis makanan yang sering disajikan dalam pesta ataupun yang sering dikonsumsi sehari-hari yaitu ayam santan, babi tore, babi bakar, brenebon babi, babi putar, babi garo rica, tinorangsak, 
pangi babi, paniki, babi asam manis, babi kecap, RW, sup kuah asam babi, tinutuan (bubur Manado), sayur pait, kotey, ikan cakalang goreng, ikan laut wokublanga, ikan mujair bakar, ikan mujair goreng, ikan cakalang fufu saos, ikan mas bakar rica, ikan mas wokublanga, ikan mas goreng, kangkung tumis, tikus, dan sayur rica rodo. Jenis makanan tersebut diketahui mengandung asam lemak jenuh, namun untuk tinutuan atau bubur manado adalah makanan yang asam lemak jenuhnya terendah (15). Rata-rata lansia mengonsumsi makanan tersebut 1-2 kali dalam seminggu. Sehubungan dengan kebiasaan budaya pesta tersebut, yang menyebabkan setiap lansia mempunyai kemungkinan untuk terpapar makanan yang mengandung asam lemak jenuh.

Asupan lemak tak jenuh berhubungan dengan penurunan tekanan darah sistolik dan diastolik (16). Hasil penelitian menunjukkan bahwa lansia yang sering mengonsumsi lemak tidak jenuh mempunyai risiko 0,219 kali lebih rendah untuk mengalami hipertensi dibandingkan dengan lansia yang jarang mengonsumsinya. Asam lemak tak jenuh sebagai faktor protektif terhadap hipertensi. Lansia dalam penelitian ini sering mengonsumsi jenis makanan sumber asam lemak tak jenuh seperti ikan tongkol (cakalang) kuah asam, tetapi ada juga lansia yang lebih menyukai makanan ikan laut yang disantan atau digoreng.

Salah satu faktor utama penyebab terjadinya hipertensi adalah aterosklerosis yang didasari konsumsi lemak berlebih. Oleh karena itu, pembatasan konsumsi lemak sebaiknya dimulai sejak dini sebelum hipertensi muncul, terutama pada orang yang mempunyai riwayat hipertensi dan pada orang menjelang usia lanjut (7).

Pengaruh asupan natrium terhadap timbulnya hipertensi terjadi melalui peningkatan volume plasma, curah jantung, dan tekanan darah (17). Konsumsi natrium yang berlebih menyebabkan konsentrasi natrium dalam cairan ekstraseluler meningkat, untuk menormalkannya, cairan intraseluler ditarik keluar sehingga volume cairan ekstraseluler meningkat. Meningkatnya volume cairan ekstraseluler itu menyebabkan meningkatnya volume darah sehingga berdampak pada timbulnya hipertensi (7). Namun penelitian ini tidak menunjukkan adanya pengaruh yang bermakna antara asupan natrium dengan kejadian hipertensi.

Sebagian besar lansia dalam penelitian ini jarang mengonsumsi bahan makanan sumber natrium termasuk garam sebagai bumbu. Hal ini diketahui dari hasil analisis yang menunjukkan bahwa 96,1\% lansia yang hipertensi, jarang mengkonsumsi natrium, demikian juga dengan $94,7 \%$ lansia yang tidak hipertensi. Umumnya para lansia sudah mengetahui perlunya membatasi konsumsi natrium, termasuk lansia yang hipertensi. Selain itu, mereka jarang mengonsumsi bumbu penyedap masakan seperti Monosodium Glutamat (MSG), kecap, sambal botol, saos tomat, tauco, dan lain sebagainya. Lansia lebih sering menggunakan bumbu alami seperti jahe, kunyit, pala, kemangi, dan bawang putih sebagai penyedap masakan. Berbeda dengan penelitian yang dilakukan di Puskesmas Mergangsan Yogyakarta menyatakan adanya hubungan bermakna antara asupan natrium dan tekanan darah, yaitu subjek dengan asupan natrium tinggi berisiko untuk menderita hipertensi 4,69 kali lebih besar. Diketahui subjek penelitian sering mengonsumsi bahan makanan sumber natrium seperti garam, kecap, sosis, jeroan, telur asin, ikan asin, mie instan, dan biskuit kaleng (18).

Rata-rata asupan kalium pada lansia yang hipertensi maupun tidak hipertensi dalam penelitian ini di atas 2000 mg per hari. Pada umumnya lansia sering mengonsumsi sayuran dan buah (pisang, bayam, wortel, tomat) sebagai bahan makanan sumber kalium. Banyak mengonsumsi kalium akan meningkatkan konsentrasinya di dalam cairan intraseluler sehingga cenderung menarik cairan dari bagian ekstraseluler dan menurunkan tekanan darah. Cara kerja kalium berlawanan dengan natrium, dengan demikian konsumsi natrium perlu diimbangi dengan kalium (13). Penelitian ini tidak menunjukkan adanya pengaruh yang bermakna antara asupan kalium terhadap kejadian hipertensi, berbeda dengan hasil penelitian di Puskesmas Mergangsan Yogyakarta yang membuktikan bahwa antara asupan kalium dan tekanan darah terdapat hubungan yang bermakna, yaitu orang yang asupan kaliumnya kurang memiliki risiko mengalami tekanan darah tinggi (18).

Rata-rata asupan kalsium pada lansia kurang dari $800 \mathrm{mg}$ per hari. Hal ini dapat disebabkan oleh kemampuan mengunyah atau masalah gigi pada lansia sehingga kurangnya asupan bahan makanan maupun hasil olahan yang mengandung kalsium. Buah-buahan mentah, sayuran, dan kacang-kacangan sering dihindari karena tidak dapat dikunyah atau ditelan, atau mungkin terlalu mahal misalnya produk susu (19). Kalsium adalah salah satu komponen gizi utama dalam produk susu. Diit kalsium dapat menurunkan aktivitas sistem reninangiotensin, meningkatkan keseimbangan natriumkalium, dan menghambat konstriksi vaskular sel otot polos. Asupan tinggi kalsium memfasilitasi peningkatkan sensitivitas insulin yang juga berkontribusi terhadap pengurangan tekanan darah. Bukti dari studi epidemiologi telah mendukung hubungan antara asupan kalsium yang memadai dapat menurunkan hipertensi atau mengurangi risiko. Meningkatkan kadar kalsium dalam diit dapat menurunkan risiko terjadinya tekanan darah tinggi dan dapat menurunkan tekanan darah pada penderita hipertensi (20).

\section{Konsumsi alkohol terhadap hipertensi}

Tidak semua lansia mengonsumsi alkohol, tetapi di antara mereka yang mengonsumsinya, terlihat berbagai pola penggunaannya (21). Pada beberapa populasi, konsumsi minuman keras selalu berkaitan dengan tekanan 
darah tinggi (22). Pernyataan tersebut juga didukung oleh hasil penelitian ini, yaitu lansia yang mengonsumsi alkohol mempunyai risiko 2,8 kali lebih tinggi untuk mengalami hipertensi dibandingkan dengan lansia yang tidak mengonsumsi alkohol.

Hubungan antara konsumsi alkohol yang berat dan hipertensi telah ditunjukan dengan jelas dalam berbagai penelitian epidemiologis. Kira-kira 5\% dari kasus hipertensi penyebabnya adalah alkohol (23). Dalam penelitian ini dibuktikan adanya pengaruh antara konsumsi alkohol dengan terjadinya hipertensi. Begitu juga dengan penelitian yang dilakukan pada pria dewasa di Korea, didapatkan bahwa mereka yang mengkonsumsi $30 \mathrm{~g}$ alkohol per hari berisiko mengalami hipertensi (24). Pengaruh alkohol terhadap kenaikan tekanan darah telah dibuktikan. Mekanisme peningkatan tekanan darah akibat alkohol masih belum jelas. Namun, diduga peningkatan kadar kortisol dan peningkatan volume sel darah merah serta kekentalan darah berperan dalam meningkatkan tekanan darah (1).

Minuman beralkohol adalah semua jenis minuman yang mengandung etanol, termasuk Cap Tikus, anggur, bir, dan saguer. Sebagian besar lansia dalam penelitian ini mengonsumsi Cap Tikus. Cap Tikus adalah jenis cairan berkadar alkohol rata-rata $30-40 \%$ yang dihasilkan melalui penyulingan saguer (cairan putih yang keluar dari mayang pohon enau). Tinggi rendahnya kadar alkohol pada Cap Tikus tergantung pada kualitas penyulingan. Semakin bagus sistem penyulingannya, semakin tinggi pula kadar alkoholnya. Saguer sejak keluar dari mayang pohon enau sudah mengandung alkohol sekitar kurang dari 5\% (25).

Peminum alkohol harian ternyata mempunyai tingkat tekanan darah yang lebih tinggi dibandingkan dengan peminum sekali seminggu, berapapun jumlah total yang diminum setiap minggunya (2). Umumnya petani Minahasa sebelum pergi ke kebun, minum 1 sloki atau 1 gelas ukuran kecil minuman beralkohol (Cap Tikus). Minuman ini dikenal oleh setiap orang Minahasa sebagai minuman penghangat tubuh, penambah nafsu makan, dan pendorong semangat untuk bekerja. Konsumsi alkohol sebanyak 1-2 sloki oleh lansia dalam penelitian ini ternyata mempengaruhi terjadinya hipertensi. Begitu juga dengan penelitian di Amerika yang menyimpulkan bahwa wanita peminum alkohol yang tergolong ringan dan sedang potensi risiko hipertensinya rendah, sedangkan pada pria risiko terjadinya hipertensi lebih tinggi. Hal ini dapat dipengaruhi oleh perbedaan pola minum, pilihan minuman, dan gaya hidup, yang dihubungkan dengan kebiasaan konsumsi alkohol pada pria maupun wanita (26).

Kandungan alkohol bukan berapa banyak alkohol yang diminum, tetapi berapa banyak kadar alkohol dalam minuman tersebut karena kadar alkohol yang menentukan berapa banyak yang diserap oleh tubuh. Pada kadar alkohol yang berbeda, kecepatan penyerapan ke dalam tubuh juga berbeda. Alkohol paling cepat diserap pada kadar dalam minuman antara $10-30 \%$ (27). Pada penelitian ini, lansia yang mengonsumsi alkohol lebih dari 5 sloki berisiko mengalami hipertensi tetapi tidak ada pengaruh yang bermakna. Hal ini dapat dipengaruhi oleh jenis minuman yang mereka konsumsi yaitu bir atau saguer yang memiliki kandungan alkohol rendah. Minuman ini sering dikonsumsi menggunakan ukuran gelas $( \pm 200 \mathrm{cc}$ ) dan biasanya dikonsumsi saat menghadiri pesta.

Berbagai penelitian mencoba mengonfirmasi pengaruh konsumsi alkohol terhadap risiko penyakit kardiovaskuler dan para ahli menduga bahwa alkohol dapat mengurangi risiko penyakit kardiovaskuler dengan mekanisme menurunkan tekanan darah. Namun efek yang tampaknya menguntungkan ini hanya diperoleh jika alkohol dikonsumsi dalam jumlah kecil sampai sedang. Tetapi belum ada konsensus medis mengenai seberapa banyak yang dikatakan sebagai konsumsi alkohol dalam jumlah sedang. Sebaliknya jika mengonsumsi alkohol dalam jumlah besar dapat berdampak buruk pada sistem kardiovaskuler yaitu hipertensi (27).

Lansia dalam penelitian ini sebagian besar telah mengonsumsi alkohol selama lebih dari 30 tahun atau sejak berusia muda. Lamanya mengonsumsi alkohol juga berpengaruh sebagai faktor risiko terjadinya hipertensi. Pola penggunaan alkohol pada lansia juga bervariasi, lansia yang mulai menggunakan alkohol secara berlebihan sejak masa dewasa muda menunjukkan ketergantungan alkohol. Penggunaan alkohol secara kronis meningkatkan tekanan darah dan pengaruhnya lebih banyak pada tekanan sistolik (28). Demikian juga dengan lansia yang mengonsumsi alkohol kurang dari 10 tahun dapat berisiko mengalami hipertensi. Hasil penelitian ini menunjukkan bahwa sejumlah subjek mulai mengonsumsi alkohol di saat memasuki usia lanjut atau pra lansia. Alasan lansia yang baru mengonsumsi alkohol di akhir hidupnya yaitu sebagai respons terhadap peristiwa-peristiwa hidup seperti rasa berduka, kesehatan memburuk, atau kesepian (21).

Pola konsumsi alkohol selama 11-30 tahun dalam penelitian ini menunjukkan risiko lebih rendah terhadap kejadian hipertensi. Hal ini diduga karena lansia yang termasuk dalam kelompok ini sebagian besar wanita yang mengonsumsi alkohol rata-rata 1 sloki sekali seminggu atau kurang dari itu. Wanita peminum alkohol yang tergolong ringan dan sedang, risiko hipertensinya lebih rendah (25).

\section{Faktor lain terhadap hipertensi}

Pada usia lanjut, hipertensi ditemukan terutama hanya berupa kenaikan tekanan darah sistolik. Tingginya hipertensi sejalan dengan bertambahnya umur yang disebabkan oleh perubahan struktur pada pembuluh darah besar, sehingga lumen menjadi lebih sempit dan dinding pembuluh darah menjadi lebih kaku, sebagai 
akibatnya adalah tekanan darah sistolik meningkat (1). Tekanan darah diastolik juga cenderung meningkat dengan bertambahnya umur, tetapi dengan laju lebih rendah dari pada tekanan sistolik, nilainya rata-rata turun setelah usia 50 tahun (22). Begitu juga dalam penelitian ini, kasus hipertensi banyak ditemukan pada lansia umur 63-65 tahun dibanding lansia umur 60-62 tahun.

Jenis kelamin berpengaruh pada terjadinya hipertensi, di mana pria lebih banyak yang menderita hipertensi dibandingkan wanita dengan rasio sekitar 2,29 untuk peningkatan tekanan darah sistolik. Pria diduga memiliki gaya hidup yang cenderung dapat meningkatkan tekanan darah dibandingkan wanita. Pada wanita, peningkatan risiko tekanan darah terjadi setelah menopause karena menurunnya hormon estrogen. Bahkan setelah usia 65 tahun, kejadian hipertensi pada wanita lebih tinggi dibandingkan pria (1). Demikian juga pada penelitian ini, pasien hipertensi lebih banyak pada wanita, hal ini dipengaruhi juga oleh jumlah subjek penelitian yang sebagian besar adalah wanita.

Obesitas mempunyai kaitan erat dengan terjadinya hipertensi dikemudian hari. Obesitas terjadi akibat mengonsumsi kalori lebih banyak daripada yang dibutuhkan oleh tubuh. Ada kecenderungan lansia memilih makanan lunak yang seringkali mempunyai kandungan energi tinggi, misalnya jenis karbohidrat atau lemak. Lingkungan juga memegang peranan penting dalam kasus obesitas, misalnya apa yang dimakan dan berapa kali makan dalam sehari, serta bagaimana aktivitasnya. Hampir semua lansia dalam penelitian ini mengonsumsi kalori lebih dari angka kecukupan gizi (AKG).

Pada kondisi obesitas, terjadi peningkatan jumlah asam lemak bebas yang akan mempersempit pembuluh darah sehingga tekanan darah meningkat. Daya pompa jantung dan sirkulasi volume darah penderita obesitas dengan hipertensi menjadi lebih tinggi dibanding dengan yang berat badannya normal (17). Hasil analisis membuktikan adanya pengaruh antara obesitas terhadap hipertensi. Tetapi setelah dikontrol dengan faktor lain, tidak ada pengaruh yang bermakna walaupun berisiko menyebabkan hipertensi. Perbedaan ini dapat disebabkan oleh asupan lemak, konsumsi alkohol, stres, dan asupan kalium sebagai faktor risiko hipertensi, yang secara bersama dapat terpapar pada subjek penelitian ini, sehingga dapat melemahkan pengaruh obesitas terhadap terjadinya hipertensi. Penelitian lain yang menggunakan RLPP sebagai indikator obesitas, membuktikan bahwa perempuan dengan RLPP lebih dari atau sama dengan 0,8 mempunyai risiko 11,5 kali untuk menderita hipertensi. Namun hasil analisis menunjukan tidak ada hubungan RLPP dengan hipertensi (29). Hasil penelitian yang berbeda menyatakan bahwa ada hubungan yang bermakna antara obesitas dan peningkatan tekanan darah pada wanita muda di Malaysia (30).
Apabila riwayat hipertensi didapatkan pada kedua orang tua, maka kemungkinan menderita hipertensi menjadi lebih besar. Hipertensi juga banyak dijumpai pada penderita kembar monozigot (satu telur), apabila salah satunya menderita hipertensi. Fakta ini mendukung dugaan bahwa faktor keturunan mempunyai peran dalam terjadinya hipertensi, baik secara langsung maupun tidak langsung. Teori ini juga didukung oleh penelitian di Bengkulu yang juga membuktikan bahwa lansia dengan riwayat keluarga hipertensi mempunyai risiko 2,28 kali lebih besar mengalami hipertensi (14). Berbeda dengan penelitian ini yang menunjukkan bahwa tidak ada pengaruh riwayat keluarga hipertensi terhadap terjadinya hipertensi. Lingkungan keluarga juga dapat mempengaruhi pola makan atau kebiasaan makan anggota keluarga yang satu dengan yang lain, terutama dalam memilih menu makanan dan cara pengolahan.

Berbagai penelitian telah menunjukkan bahwa merokok, baik yang dilakukan sesekali maupun kronis serta paparan rokok pasif dapat menyebabkan arteri menjadi kaku, sehingga menghalangi arteri mengembang ketika otot dan jantung membutuhkan oksigen lebih banyak. Arteri yang kaku meningkatkan tekanan pada jantung sehingga mengakibatkan hipertensi (2). Hasil analisis membuktikan bahwa tidak ada hubungan antara merokok dengan terjadinya hipertensi. Hal ini kemungkinan disebabkan oleh sebagian besar lansia dalam penelitian ini wanita dan tidak merokok atau sebagai perokok pasif. Begitu juga dengan penelitian di Korea yang menemukan bahwa status merokok tidak berpengaruh terhadap kejadian hipertensi (24). Berbeda dengan hasil penelitian di RS Haji Surabaya yang secara umum menyimpulkan bahwa merokok merupakan faktor risiko terhadap kejadian hipertensi (31).

Stres dapat merangsang kelenjar anak ginjal melepaskan hormon adrenalin dan memacu jantung berdenyut lebih cepat serta lebih kuat, sehingga tekanan darah akan meningkat (1). Stres dapat mengakibatkan tekanan darah naik untuk sementara waktu. Jika stres telah berlalu, maka tekanan darah biasanya akan kembali normal (13). Pada penelitian ini tidak ditemukan adanya pengaruh stres terhadap terjadinya hipertensi. Hasil penelitian lain juga menyimpulkan bahwa stres dan tekanan psikologis tidak berhubungan dengan hipertensi. Hubungan antara peristiwa-peristiwa stres dengan hipertensi dilaporkan bukan karena efek stres pada tekanan darah dan mungkin dianggap berasal dari perasaan negatif tentang penyakit dan bukan karena penyakit itu sendiri (32).

\section{KESIMPULAN DAN SARAN}

Berdasarkan hasil penelitian dapat diketahui bahwa pola makan tinggi lemak dan konsumsi alkohol berpengaruh terhadap terjadinya hipertensi pada lansia di Kota Tomohon, namun tidak ada pengaruh yang bermakna 
dari pola makan bahan makanan sumber natrium, kalium, dan kalsium terhadap terjadinya hipertensi. Oleh karena itu, pola makan yang tinggi lemak dan kebiasaan mengonsumsi alkohol harus dihindari oleh masyarakat sejak usia muda. Bagi lansia, penting diberikan informasi untuk mencegah dan menghindari pola konsumsi makanan tinggi lemak dan minuman beralkohol yang dapat meningkatkan risiko hipertensi melalui program penyuluhan kesehatan lansia di posyandu atau kelompok lansia. Selain itu, pada penyajian menu makanan saat pesta sebaiknya jenis makanan maupun minuman beralkohol dikurangi dan lebih banyak disajikan buah dan sayuran.

\section{RUJUKAN}

1. Departemen Kesehatan RI. Pedoman teknis penemuan dan tatalaksana penyakit hipertensi. Jakarta: Departemen Kesehatan RI; 2006.

2. Kaplan NM. Clinical hypertension. Sixth edition. Baltimore: Wiliam \&Wilkins; 1994.

3. Handajani YS. Penyakit kronis pada masyarakat lanjut usia dalam hubungan dengan perilakunya di DKI Jakarta. Majalah Kesehatan Perkotaan 2005;12(2):1-8.

4. Badan Pusat Statistik. Perkembangan beberapa indikator utama sosial ekonomi Indonesia. Jakarta: BPS; 2011.

5. Dinas Kesehatan dan Kesejahteraan Sosial. Profil kesehatan. Tomohon: Dinkes; 2009.

6. Departemen Kesehatan RI. Riset kesehatan dasar tahun 2007. Laporan Nasional. Jakarta: Departemen Kesehatan RI; 2008.

7. Saraswati S. Diet bagi penderita penyakit hipertensi. Dalam: Diet sehat untuk penyakit asam urat, diabetes, hipertensi, dan stroke. Yogyakarta: A-plus Books; 2009.

8. Russel ML, Cooper ML, Frone MR, Welte JW. Alcohol drinking patterns and blood pressure. Am J Public Health 1991;81(4):452-7.

9. Sudarma M. Makanan makna budaya dan kesehatan. Sosiologi untuk kesehatan. Jakarta: Salemba Medika; 2008.

10. The Seventh Report of The Joint National Committee. Prevention, detection, evaluation, and treatment of high blood pressure. Maryland: NIH Publication; 2003.

11. Madiyono B, Moeslichan S, Sastroasmoro S, Budiman I, Purwanto H. Perkiraan besar sampel. Dalam: Sastroasmoro S, Ismael S. Dasar-dasar metodologi penelitian klinis. Edisi 3. Jakarta: Sagung Seto; 2008.

12. Sukardji K. Penatalaksanaan gizi mutakhir: diabetes mellitus. Prosiding Temu IImiah Kongres XIII PERSAGI dan Festival Gizi; 2005 Nov 20-24; Bali. Jakarta: PERSAGI; 2005.

13. Puspitorini M. Cara mudah mengatasi darah tinggi. Yogyakarta: Image Press; 2008.
14. Riyadi A, Wiyono P, Budiningsari RD. Asupan gizi dan status gizi sebagai faktor resiko hipertensi esensial pada lansia di Puskesmas Curup dan Perumnas Kabupaten Rejang Lebong Propinsi Bengkulu. Jurnal Gizi Klinik Indonesia 2007;4(1):43-51.

15. Kandou GD. Makanan etnik Minahasa dan kejadian penyakit jantung koroner. Jurnal Kesehatan Masyarakat Nasional 2009;4(1):42-8.

16. Gurr MI. Fats. In: Garrow. Human nutrition and dietetics. Tenth Edition. London: Churchill Livingstone; 2000.

17. Susalit E, Kapojos EJ, Lubis HR. Hipertensi primer. Dalam: Suyono SH. Buku ajar ilmu penyakit dalam. Edisi 3. Jakarta: Balai Penerbit FK UI; 2001.

18. Ernitasari PD, Djarwoto B, Siswati T. Pola makan, rasio lingkar pinggang pinggul (RLPP) dan tekanan darah di Puskesmas Mergangsan Yogyakarta. Jurnal Gizi Klinik Indonesia 2009;6(2):71-7.

19. Stanley M. Penuaan pada sistem gastrointestinal dengan pertimbangan nutrisi. Dalam: Stanley $M$, Beare PG. Buku ajar keperawatan gerontik. Ed 2. Juniarty M, Meiliya E. (Alih bahasa). Jakarta: EGC; 2007.

20. Wang L, Manson JE, Buring JE, Lee IM, Sesso HD. Dietary intake of dairy products, calcium, and vitamin D and the risk of hypertension in middle-aged and older women. Hypertension 2008;51(4):1073-9.

21. Holland BE. Masalah-masalah alkohol pada lansia. Dalam: Stanley M, Beare PG. Buku ajar keperawatan gerontik. Ed 2. Juniarty M, Meiliya E. (Alih bahasa). Jakarta: EGC; 2007.

22. Padmawinata K. Pengendalian hipertensi. Laporan Komisi Pakar WHO. Bandung: Penerbit ITB; 2001.

23. Masters SB. Alkohol. Dalam: Katzung BG. Farmakologi dasar dan klinik. Sjabana. (Alih bahasa). Jakarta: Salemba Medika; 2002.

24. Lee SH, Kim YS, Sunwoo S, Huh BY. A retrospective cohort study on obesity and hypertension risk among Korean adults. J Korean Med Sci 2005;20(2):188-95.

25. Barlina R, Karouw S, Pasang P. Pengaruh sabut kelapa terhadap kualitas nira aren dan palm wine. Jurnal Litri 2006;12(4):166-71.

26. Sesso HD, Cook NR, Buring JR, Manson JE, Gaziano JM. Alcohol consumption and the risk of hypertension in women and men. Hypertension 2008;51(4):1080-7.

27. Nurwijaya H, Ikawati Z. Bahaya alkohol dan cara mencegah kecanduannya. Jakarta: Elex Media Komputindo; 2009.

28. Joewana S. Gangguan mental dan perilaku akibat penggunaan zat psikoaktif. Jakarta: EGC; 2005.

29. Widyastuti N, Subagio HW. Hubungan beberapa indikator obesitas dengan hipertensi pada perempuan. Media Medika Indonesiana 2006;41(1):10-6.

30. Khan J. Obesity and blood pressure of female Malaysian students, utilizing the newly proposed classification of 
body mass index for Asians. International Medical Journal 2008;15(2):153-6.

31. Martini S, Hendrati LY. Usia merokok pertama kali merupakan faktor yang meningkatkan risiko kejadian hipertensi: besar risiko kejadian hipertensi menurut pola merokok. Jurnal Kedokteran Yarsi 2006;14(3):191-8.
32. Sparrenberger F, Fuchs SC, Moreira LB, Fuchs FD. Stressful life events and current psychological distress are associated with self reported hypertension but not with true hypertension: results from a crosssectional population-based study. BMC Public Health 2008;8:357. 